\title{
The Potentials of Spring Water in Brintik Indonesia as the Stroke Therapy Medium
}

\author{
Anita Puspa Ningrum \\ Master Program in Sport Sciences \\ Universitas Negeri Yogyakarta \\ Yogyakarta, Indonesia \\ pn.anita.2017@student.uny.ac.id
}

\author{
B. M. Wara Kushartanti \\ Faculty of Sport Sciences \\ Universitas Negeri Yogyakarta \\ Yogyakarta, Indonesia \\ wkushartanti@gmail.com
}

\begin{abstract}
Umbul Brintik (Brintik Spring Water), located at Central Java Indonesia has a therapy pool mainly for sick people. There's this long age myth about the existence of a big tree near the pool said or believed to have magical effects for heal sick people. This has attracted many people to the pool. However, the fact still remains that the pool is maximally oxygenated by the photosynthesis process that occur on the leaves of the big tree. This research work was conducted in Umbul Brintik from March to April 2018. 45 persons at the pool were randomly chosen as samples. The research used a nonparametric statistical analysis test with SPSS. The interview reveals that there are $32.5 \%$ stroke patients, $27.3 \%$ diabetic patients, $13 \%$ HNP patients, $6.4 \%$ asthmatic people, and $20.3 \%$ others. These research made use of a protocol study based on observations, interviews, and documentation. There was a therapist with 6 years' experience who trained the local people. There was one main pool that was used for therapy, two whirlpools, and two recreational pools. The facilities includes a parking lot, lockers, and canteen serving traditional food. This study concludes that Umbul Brintik is a highly potential stroke therapy center.
\end{abstract}

Keywords-aquatic, health, water therapy, stroke therapy.

\section{INTRODUCTION}

Indonesia is presently experiencing a series of phases, which are the epidemic transition, demographic transition, and technological transition. These phases have caused some changes in disease patterns, from contagious to non contagious diseases. An Aquatic physical therapy is defined as the health, fitness, prevention, and rehabilitation of stroke patients in an aquatic environment ${ }^{[1][8]}$. A research that was conducted in 2014 proved that aquatic therapy enabled seven stroke patients to walk ${ }^{[2][5]}$. A prospective study has proved that an estimated 795.000 people in the US suffer from stroke annually ${ }^{[3]}$. The eight weeks exercises have also been proven to have positive impacts on the patients by reducing fatigue, strengthening muscles, stomach, lower limb, and also by improving the patients' mood (tense, depression, and anger) ${ }^{[4][6]}$. The water submerging exercise to the hips also improves the sensory and motor cerebral cortex ${ }^{[1]}$. Halliwicks' concept of aquatic therapy has to do with the structural learning progress and this is aimed at improving ones' self reliance in water, the ability to control ones' movement, and ones' postural balance ${ }^{[7][8]}$. It is important to diagnosis a stroke patient, this helps to observe the patient's vascular risk factors ${ }^{[9]}$. Some symptoms that are related to stroke are hypertension, diabetes, smoking habit, hyperlipidemia, heredity, sex, and age. Nevertheless, some people without these factors may also experience stroke. In the US one person dies every four minutes because of stroke so a measure known as the accurate early stroke treatment has been introduced ${ }^{[10]}$.

Neema explained a study, on the evidence of cell death as one of the causes of stroke ${ }^{[11]}$. This process is called biochemical process. It is claimed that the concepts of stroke prevention and recuperation has been proven to be more effective in ways that are harmless to the other organs. Thus, it prevents complications. It is also a known fact that aquatic therapy can help stroke patients or people with neurological logic disorders to enhance and obtain optimum mobility [12] [8]. Aquatic exercises for stroke patients using water as resistance involves the arm muscles, shoulders, back, stomach, and feet ${ }^{[13]}$. The systematic reviews regarding the effectiveness of aquatic therapy showed that it improved the dynamic balance and walking speed of stroke patients [12].

The purpose of this therapy is to provide a safe balance exercise, that would prevent falling, and also minimize the fear of falling ${ }^{[14]}$. The exercise should be done three times a week for eight weeks from mild to average level ${ }^{[15]}$. The objective of submerging the whole body from the neck down to the feet in a standing position in the water to helps to train the periphery muscles or the central circulatory system. Water can reduce the stress on bones, joints, and muscles because of the body's ability to float in water, and this is as a result of the density, hydrostatic and viscosity pressure of the water ${ }^{[16]}{ }^{[5]}$. This makes it possible for the stroke patients to be able to learn some movement which cannot be performed on land. about 200 stroke patients visits Umbul Brintik daily. Most, patients suffering from various diseases, visit this place regularly for water therapy not necessarily because they want to swim or relax. A whole lot of these people come from different neighbouring cities, and they usually come with some of their family members. These people believe that the big bayan tree from which the spring water comes out has magical powers believed to be the remedy for many kinds of diseases. Such belief contributes to the improvement of their health even though the improvement is as a result of regular physical; exercises and the high mineral content of the spring water. 


\section{METHOD}

This research was designed in a such a way that a protocol type of study was used, the researcher carefully examined the results of the observations, interviews, and documentation of the various variables contributing to the mortality of stroke patients, such as diabetes, HNP, asthma, hypertension, headache, obesity, cataract, neuropathic, calcification, and heart diseases.

This research was conducted at Umbul Brintik in Klaten, Central Java from March to April 2018. Three techniques were used to collect data: observation, interviews and documentation. The interviews were conducted in order to obtain the patients' initials, age, sex, occupation, type of illness, and the period of illness. the natural therapy method involved all kinds of of exercises done, excluding swimming. The questions in the interview were designed in accordance with the observation sheet of the protocol study.

45 persons who regularly swarm three to four times in a week from 2017 till date were used as case study in this research work. Samples were also obtained from stroke patients from neighbouring cities of Umbul Brintik who swam for health therapy from the months of March to April 2018.

Samples were selected by using a non probability sampling method with quota sampling and incidental sampling. The 45 samples were determined randomly based on the number of visitors that came to Umbul Brintik.

The analysis of the data that was obtained from the research setting was aimed at descriptively identifying the illness, the length of the illness, swimming techniques, and the other types of exercises that were implemented. The data was displayed to find the relationship among the variables. The SPSS was used to test the nonparametric statistical analysis.

\section{RESULTS AND DISCUSSION}

Klaten Central Java geographically located in the eastern foot of the Merapi Mountain in Indonesia has a lot of spring waters. A study by FMIPA UNS (the Faculty of Mathematics and Science of the Sebelas Maret University in Solo, Indonesia) reported that there are 191 spring waters in the 17 districts of Klaten region, of which Umbul Brintik is one of them.

A survey was conducted for 2 months from 4 to 6 a.m, three times in a week with over 60 people in the pool. they were submerged in the pool for 10 minutes, and their activities include swimming around for 15 minutes, moving their legs and feet at the rim of the pool, massaging their backs by standing with their backs behind the water running from the pipe, swimming by using inflatable swimming aid, jumping from the rim of the pool, and walking in the water, until their bodies became cool.

It was observed, that there were a total of 4.800 visitors but only 45 persons were available for the interview. The others refused to participate in this study, because they were not willing to be identified as patients suffering from a certain disease and they also weren't comfortable wearing swimming outfit during the interview. The frequency of therapy depended on their availability. For example, the retired patients living nearby visted the pool every morning or every other day, those working visited the pool every week and people from neighbouring towns visited once a month.

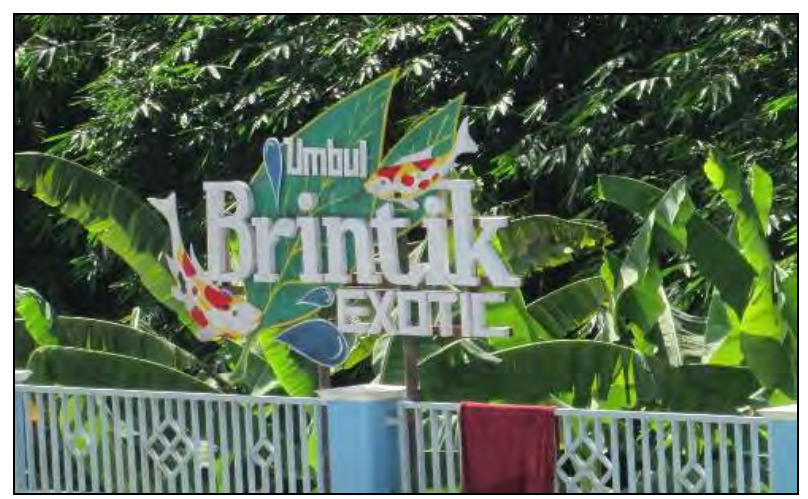

Fig. 1. Umbul Brintik, Central Java, Indonesia

From the protocol study that was conducted on the $1^{\text {st }}$ of March to the $31^{\text {st }}$ of April, it was observed that people from Central Java, East java, and Jogjakarta visited Umbul Brintik. Some of these people suffered from stroke, diabetes, heart diseases, hypertension and gastric acid. While the Others came to swim or to submerged in the pool.

Umbul Brintik is a swimming pool used for health therapy and for physical exercise by patients with various illnesses. It is situated in Sentul Malangjiwan, Kebonarum, Klaten, Central Java, Indonesia. The results obtained from the observations, interviews and documentation is presented in Table 1 .

\section{A. Sex}

In the beginning of the experiment, the number of respondents were 25 males and 20 females. This fact is in line with Fortuna's study (2012) which stated that the number of males suffering from stroke are $51.35 \%$ while the number of females suffering from stroke are $48.65 \%{ }^{[17]}$. Males suffering from stroke are liable to More serious risks because of the possibility of internal bleeding. Researches conducted in the USA, Great Britain, France, and Italy proves that the prevalence of stroke is more in men then in women ${ }^{[12]}$.

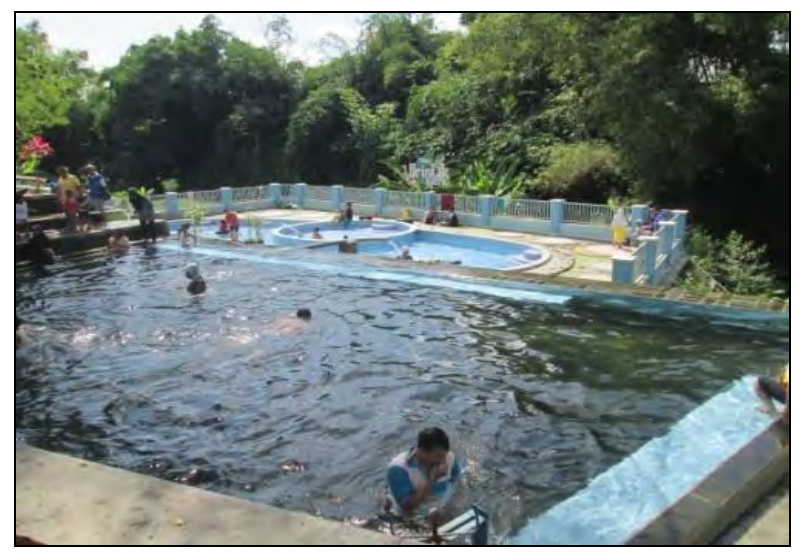

Fig. 2. Hydrotherapy Pool 
B. Age

The ages of the respondents were from 22 to 88 years old. The standard deviation was 13.5213. Stroke mortality was predicted to occur in patients that experienced hemogaric stroke at the age of $60^{[18]}$. People who suffer from stroke at an old age could experience worse conditions [19-21].

\section{Occupation}

According to Table 1, one could deduce that the highest group was the retired and the employees. In Korea, the respondents were catagorized into two groups, education and occupation [22-24]. Similarly in Indonesia, stroke is common among low and middle class.

\section{Types of illness}

Stroke is caused by several degenerative illnesses, and it could worsen if they patient has hypertension or diabetes [30][31]. Demchuck (1995) claimed that reactive hypergligemic or diabetes mellitus triggers intracellular acidosis which damages the neuron, glial and vascular tissues ${ }^{[25]}$.

\section{E. Length of illness}

Most of The respondents suffered stroke for a period of 6 months to 10 years before dying as a result of the ailment or old age. The standard deviation was calculated to be 2.2512 and the mean was calculated to be 3. It was discovered that most of the patients' condition deteriorated due to lack of knowledge about the prevention and recuperation stages of stroke ${ }^{[27-29]}$

\section{F. Natural method of therapy implemented}

Majority of the respondents in this study performed water massage and this was achieved by standing and backing the modified water pipe. Unfortunely, this therapy does not allow the patient to move actively. ${ }^{[2]}$ aquatic therapy movements are similar to land movements and this provides benefits for better health conditions. Aquatic therapy movement include warming up, postural stability, transfers in water, water massages and gym exercises in water.

\section{G. Other Types of exercise implemented}

According to Ghani et.al. (2013) the prevalence of stroke among respondents who barely participated in physical activities was higher $(2.70 \%)$ than those who participated moderately in physical activities $(0.8 \%)$. Physical impairment is the main reason while stroke patients chose aquatic therapy ${ }^{[3]}$. Exercises that involves movement of the hands, upper body and respiratory muscles are feasible. On the other hand, exercises that involves movements of the legs are not ${ }^{[3]}[7]$.
TABLE I. THE CHARACTERISTICS OF SAMPLES BASED ON SEX, AGE, OCCUPATION, TYPES OF ILLNESS, LENGTH OF ILLNESS, NATURAL SWIMMING METHOD, AND OTHER TYPES OF EXERCISE IMPLEMENTED

\begin{tabular}{|c|c|c|}
\hline Characteristics & $\begin{array}{c}\text { Number of } \\
\text { Samples and }(\mathrm{N} \\
\%)\end{array}$ & SD \\
\hline \multicolumn{3}{|l|}{$\operatorname{Sex}(N=45)$} \\
\hline Male & 25 & \\
\hline Female & 20 & \\
\hline Age (year) $(\mathrm{N}=45)$ & & 13,5213 \\
\hline $22-31$ & $3(6,67 \%)$ & \\
\hline $32-41$ & $1(2,22 \%)$ & \\
\hline $42-51$ & $9(20,00 \%)$ & \\
\hline $52-61$ & $14(31,11 \%)$ & \\
\hline $62-71$ & $12(26,67 \%)$ & \\
\hline $72-81$ & $5(11,11 \%)$ & \\
\hline $82-91$ & $1(2,22 \%)$ & \\
\hline \multicolumn{3}{|l|}{ Occupation $(\mathrm{N}=45)$} \\
\hline Civil Servants & $7(15,56)$ & \\
\hline Retired Civil servant & $16(20,8 \%)$ & \\
\hline Private employees & $15(33,33 \%)$ & \\
\hline Housewives & $5(11,11 \%)$ & \\
\hline University Students & $2(4,44 \%)$ & \\
\hline \multicolumn{3}{|l|}{ Types of illness $(N=77)$} \\
\hline Diabetes Mellitus & $21(27,30 \%)$ & \\
\hline Stroke & $25(32,50 \%)$ & \\
\hline HNP & $10(13,00 \%)$ & \\
\hline Asthma & $5(6,40 \%)$ & \\
\hline $\begin{array}{l}\text { Miscellaneous (hypertension, } \\
\text { headache, neuropathic, } \\
\text { calcification, cataract, stiffness, } \\
\text { obesity, ankle, and heart diseases) }\end{array}$ & $16(20,8 \%)$ & \\
\hline Length of illness $(\mathrm{N}=45)$ & & 2,2512 \\
\hline $0,5-1,5$ & $13(28,89 \%)$ & \\
\hline $2,0-3,0$ & $17(37,78 \%)$ & \\
\hline $3,5-4,5$ & $5(11,11 \%)$ & \\
\hline $5,0-6,0$ & $6(13,33 \%)$ & \\
\hline $6,5-7,5$ & $1(2,22 \%)$ & \\
\hline $8,0-9,0$ & $2(4,44 \%)$ & \\
\hline $9,5-10,5$ & $1(2,22 \%)$ & \\
\hline \multicolumn{3}{|l|}{ Natural Swimming Method $(\mathrm{N}=45)$} \\
\hline Submerging & 5 & \\
\hline Diving & 5 & \\
\hline $\begin{array}{l}\text { Moving body on the spot and by } \\
\text { swimming }\end{array}$ & 11 & \\
\hline Swimming & 9 & \\
\hline Water massage & 15 & \\
\hline \multicolumn{3}{|l|}{$\begin{array}{l}\text { Other Types of exercise } \\
\text { implemented }(\mathrm{N}=45)\end{array}$} \\
\hline None & 26 & \\
\hline Walking & 8 & \\
\hline Jogging & 2 & \\
\hline Gym exercise & 9 & \\
\hline
\end{tabular}

From the 45 respondents, we discovered a total of 77 different types of illnesses due to the fact that some of them respondents suffered from more than one illness. ${ }^{[32]} \mathrm{A}$ person is said to experience early stroke symptoms by the medical personnel (doctors, nurses, midwives) when he suddenly feels numb or weak on one side of the body, and has trouble speaking or understanding. A study conducted in 2016 showed that the number of stroke patients with diabetes mellitus was higher than that of stroke patients without diabetes mellitus ${ }^{[26][32]}$. The prevalence of stroke patients with diabetes was $6.7 \%$ and the risk was 2.96 higher in those using diabetes control medicines (95\% CI: 2.62-3, $34)$ than patients without diabetes mellitus ${ }^{[26][32] .}$ 


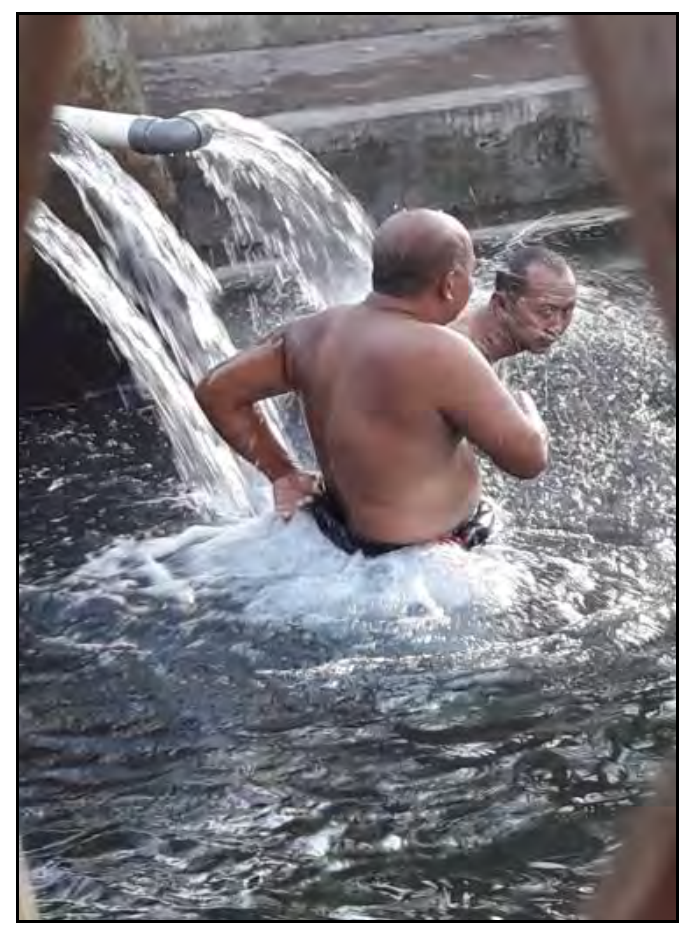

Fig. 3. Natural Method implemented

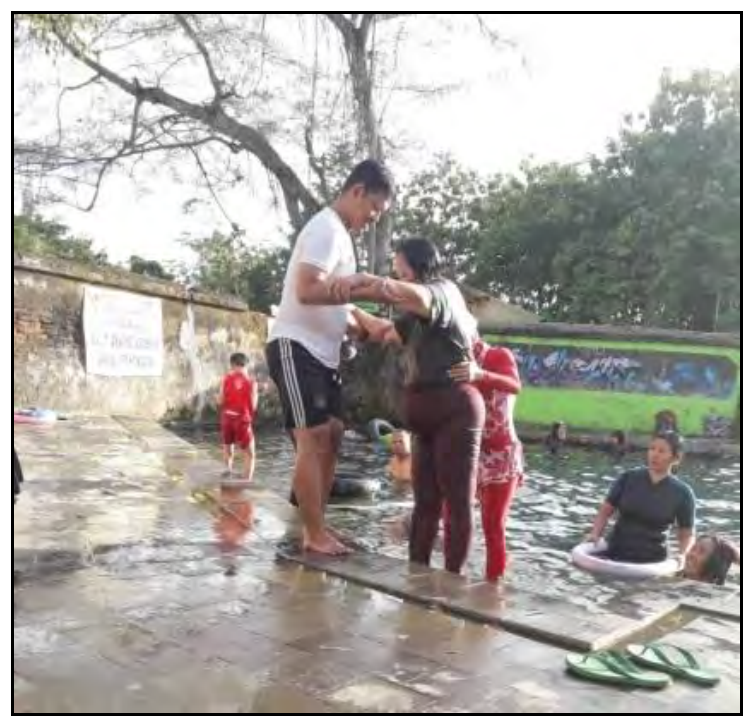

Fig. 4. Stroke Patient

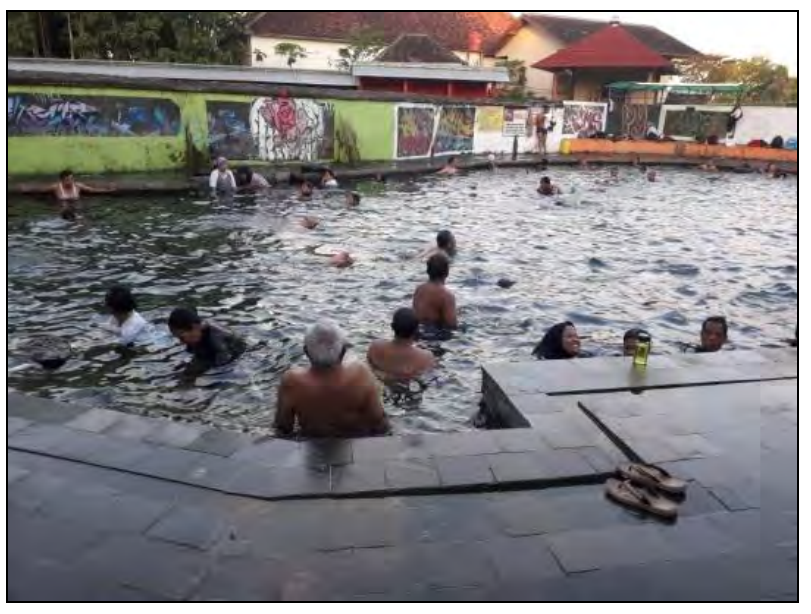

Fig. 5. Natural Swimming Method

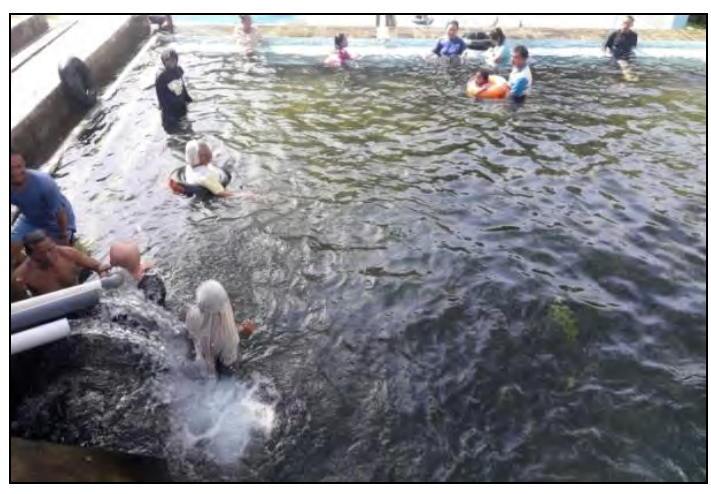

Fig. 6. Natural method implemented

\section{CONCLUSION}

Umbul Brintik, in Central Java is a pool where patients go for aquatic therapy and hydrotherapy. Hydrotherapy has been proven to improve a stroke patients' condition. The natural method that was initially learnt from therapist helps to recuperate the stroke patients' physical impairment. The therapy implemented in Umbul Brintik was considered to be a success since the number of people visiting this place increased significantly. More than $80 \%$ of the patients claimed that they felt better and healthier after a series of therapy. Other factors that contributed to their well being was the oxygenated spring water, continuous flow of the water, five pools and canteens selling healthy food such as rice and various Javanese salads, eels, and fresh water fishes.

\section{REFERENCES}

[1] S. Y. Schaefer, T. J. Louder, F. Shayla and E. Bressel, "Effect of water immersion on dual-task performance: implications for Aquatic Therapy," in Wiley Online Library, USA, 17 April 2015 (wileyonlinelibrary.com)

[2] A. R. Marinho-Buzelli1, A. M. Bonnyman, and M. C. Verrier, "The effects of aquatic therapy on mobility of individuals with neurological diseases: A systematic review," 160-500 University Avenue, Toronto, ON M5G1V7, Canada, 2014, 1-11.

[3] J. M. Veerbeek, E. van Wegen, R. van Peppen, P. J. van der Wees, E. Hendriks, M. Rietberg, G. Kwakkel, "What is the evidence for physical therapy poststroke? a systematic review and meta-analysis," Vol 9 e87987, February 2014.

[4] I. C. Villanueva, C. Ferna'ndez-Lao, A. I. Cuesta-Vargas, R. Del Moral-Avila, Ce'sar Ferna'ndez-de-las-Peñ as, M. Arroyo-Morales, "The effectiveness of a deep water aquatic exercise program in cancerrelated fatigue in breast cancer survivors: a randomized controlled trial," Archives of Physical Medicine and Rehabilitation 2013;94:22130.

[5] Z. Zhu, L. Cui, M. Yin, Y. Yu, X. Zhou, H. W. and H. Yan, "Hydrotherapy vs. conventional land-based exercise for improving walking and balance after stroke: A rando-mized controlled trial," Clinical Rehabilitation, China, 2015 pp $1-7$.

[6] K. Duffy, "Aquatic therapy for a patient post- stroke: A case report," 2014.

[7] J. C. Montagna, B. C. Santos, C. R. Battistuzzo, A. P. C. Loureiro, "Effects of aquatic physiotherapy on the improvement of balance and corporal symmetry in stroke survivors," Vol 7(4), Int J Clin Exp Med 2014, pp 1182-1187.

[8] D. K. Noh, Jae-Young Lim, Hyung-Ik Shin and Nam-Jong Paik, "The effect of aquatic therapy on postural balance and muscle strength in stroke survivors - a randomized controlled pilot trial," Clin Rehabil 2008; 22; 966, DOI: 10.1177/0269215508091434.

[9] G. Smith, "Acute stroke - diagnosis and management," Vol 3(1), Scottish Universities Medical Journal, 2014, pp 18-27. 
[10] D. Anderson, D. Larson, A. Ferguson, J. Klaas, F. Kushner, B. Peterson, T. Sierzant, C. Streib, R. Thomson, "Health Care Guideline: Diagnosis and Initial Treatment of Ischemic Stroke," Institute for Clinical Systems Improvement, American, 2016, pp 1-70.

[11] N. Kanyal, "The science of ischemic stroke: Pathophysiology \& pharmacological treatment," Oct 2015; 4(10), International Journal of Pharma Research, pp 65-84.

[12] Byoung-Sun Park, Ji-Woong noh, Mee-young kiM, LiM-kyu Lee, Seung-Min yang, Won-Deok Lee, yong-SuB Shin, Ju-hyun kiM, Jeong-uk Lee, Taek-yong kWak, Tae-hyun Lee, Jaehong Park, JunghWan kiM, "A comparative study of the effects of trunk exercise program in aquatic and land-based therapy on gait in hemiplegic stroke patients," The Journal of Physical Therapy Science, J. Phys. Ther. Sci. 28: 1904-1908, 2016.

[13] E. Hägglund, I. Hagerman, K. Dencker and A.Strömberg, "Effects of yoga versus hydrotherapy training on health-related quality of life and exercise capacity in patients with heart failure: A randomized controlled study," Vol. 16(5), European Journal of Cardiovascular Nursing 2017, pp $381-389$.

[14] D. Volpe, M. G. Giantin, R. Maestri and G. Frazzitta, "Comparing the effects of hydrotherapy and land-based therapy on balance in patients with Parkinson's disease: a randomized controlled pilot study," Vol. 28(12), Clinical Rehabilitation, Italy 2014, 1210 -1217.

[15] Cider $^{\circ}$ Asa, S. Maria, S. S. Katharina, and A. Bert, "Aquatic exercise is effective in improving exercise performance in patients with heart failure and type 2 diabetes mellitus," Volume 2012, Hindawi Publishing Corporation: Evidence-Based Complementary and Alternative Medicine.

[16] A. B. Wolff, "Post-op and non-op aqua therapy protocol please read entire protocol prior to initiating therapy," Washington Orthopaedics and Sports Medicine.

[17] J. F. Ivone \& Supantini, "Gambaran Penderita Stroke di Rumah Sakit Ade Moehammad Djoen Sintang Kalimantan Barat Periode Januari-Desember 2012,"

[18] J. A. Rathore, Z. A. Kango, \& A. Mehraj, "Predictors of Mortality after Acute Stroke A Prospective Hospital Based Study. Vol 23(2), J Ayub Med Coll Abbottabad, 2011, pp 144-146.

[19] Vermeer, A. Algra, Franke, Koudstaal, \& Rinkel, "Long-term prognosis after recovery from primary intracerebral hemorrhage," American Academy of Neurology, Vol 59, 2002, pp 205-209.

[20] J. Li, L. Wang, B. Chao, Y. Liu, Prevalence of stroke in China: an epidemiological study based on the National Stroke Screening Survey. The Lanset, 2015; 386, Special Issue, S49.
[21] D. Mukherjee, C. G. Patil, Epidemiology and the global burden of stroke. Vol 76(6), World Neurosurg, 2011, pp S85-90, doi:10.1016/j.wneu.

[22] Park W-B, Cho J-S, Shin S-D, Kong S-Y, Kim J-J, Lim Y-S, et al. Comparison of epidemiology, emergency care, and outcomes of acute ischemic stroke between young adults and elderly in Korean population: a multicenter observational study. Journal of Korean medical science. 2014;29(7):985-9

[23] American Heart Association. 38: 3198-3204. Februari 2017, http:// stroke.ahajournals.org/content/38/12/ 3198.

[24] D. Hu, J. Huang, Y. Wang, D. Zhang, and Y. Qu, "Fruits and vegetables consumption and risk of stroke: a meta-analysis of prospective cohort studies. STROKEAHA.114.004836 Published online before print May 8, 2014, doi: 10.1161/STROKEAHA.114.004836

[25] A. M. Demchuk, L. B. Morgenstern, D. W. Krieger, T. L Chi, W. Hu, T. H. Wein, "Serum Glucose Level and Diabetes Predict Tissue Plasminogen Activator- Related Intracerebral Hemorrhage in Acute Ischemic Stroke," Stroke; 30: 34-9, 1999.

[26] L. Ghani, L. K. Mihardja, \& Delima. Faktor Risiko Dominan Penderita Stroke di Indonesia. Bulletin Penelitian Kesehatan. 2016.

[27] A. Ann, Erwianto, A. Sari, Barack, Rossana, Hersunarti Ni, Anna A, dkk, "Pedoman tatalaksana hipertensi pada penyakit kardiovaskular," 2015, Perhimpunan Dokter Spesialis Kardiovaskular Indonesia.

[28] Centers for Disease Control and Prevention. 2014. High Blood Pressure.(Online) Tersedia di: https://www.cdc.gov/bloodpressure/ family_history.htm, Maret 2017.

[29] P. Amarenco, L. Goldstein, M. Szarek, H. Sillesen, A. Rudolph, A. Callahan, M. Hennerici, L. Simunovic, J. Zivin, \& M. Welch, Effects of Intense Low-Density Lipoprotein Cholesterol Reduction in Patients With Stroke or Transient Ischemic Attack. American Heart Association. 2007. 38: 3198-3204. Diakses 15 Februari 2017, http:// stroke.ahajournals.org/content/38/12/ 3198.full

[30] Y. Zhang, A. M. Chapman, M. Plested, D. Jackson, F. Purroy, “The Incidence, prevalence, and mortality of stroke in France, Germany, Italy, Spain, the UK, and the US: A Literature Review," Stroke Res Treat. 2012;436125. doi: 10.1155/2012/436125. Epub 2012 Mar 1. 11 pages http://dx.doi.org/10.1155/2012/436125

[31] V. Tikhonoff, H. Zhang, T. Richart, \& Staessen, "Blood Pressure as a modifiable risk factor in acute stroke," Vol 367 Lancet, 2009, pp 1747-1757.

[32] Badan Penelitian dan Pengembangan Kesehatan. Pokok-Pokok Hasi Riskesdas Indonesia tahun 2013. Jakarta: Lembaga Penerbit Balitbangkes, 2014. 